\title{
Mathematical modelling of thermal stresses within the borehole walls in terms of plasma action
}

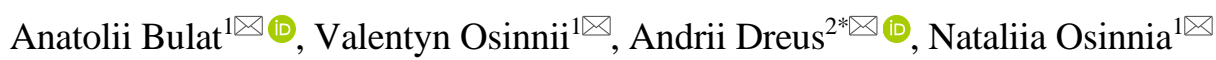 \\ ${ }^{1}$ Institute of Geotechnical Mechanics named by N. Poljakov of National Academy of Sciences of Ukraine, Dnipro, 49005, Ukraine \\ ${ }^{2}$ Oles Honchar Dnipro National University, Dnipro, 49010, Ukraine \\ *Corresponding author: e-mail dreus.andrii@gmail.com, tel.+380509662871
}

\begin{abstract}
Purpose is the development of a mathematical model to study and describe thermal processes within the borehole wall in terms of plasma-based rock breaking.

Methods. The following has been applied: theoretical analysis in the framework of a theory of brittle thermoelasticity breaking, methods of mathematical modeling, and computational experiment.

Findings. Brief information on the results of the development of advanced plasma-based technology for borehole reaming for hard mineral mining has been represented. The results of industrial tests of plasma plant of $150-200 \mathrm{~kW} \cdot \mathrm{s}$ power with plasma-generating gas in the air for hard rock breaking have been represented. The plant and plasma-based technology of borehole reaming were tested in underground conditions of Kryvbas mines while reaming a perimeter hole to drive a ventilation rise in silicate-magnetite quartzites. A mathematical model has been proposed to analyze heat and mechanical fields in the rock during the plasma-based action on the borehole walls. Numerical studies of the temperature dynamics and thermal stresses within the borehole-surrounding rock layer have been carried out. It has been demonstrated that if lowtemperature plasma is used $\left(T=3500-4000^{\circ} \mathrm{C}\right)$, thermal compressing stresses are induced within the thin rock layer; the stresses may exceed the boundary admissible ones. It has been identified that plasma-based effect on the borehole wall makes it possible to create the conditions for intense rock fracturing and breaking.
\end{abstract}

Originality. Solution of a new problem of thermoelastic state of a borehole wall in terms of plasma action has been obtained. The proposed mathematical model has been formulated in a cylindrical coordinate system and considers convective and radiation heat exchange between a plasma jet and a borehole wall.

Practical implications. The obtained results make it possible to assess the rock state depending on the plasma jet parameters. The proposed methods of calculations will help carry out research to evaluate breaking parameters (the required heating time, thickness of the heated layer, and approximate spall dimensions) and develop different methods for the breaking process control.

Keywords: plasma-based technology, thermal stresses, heat transfer, borehole reaming, mathematical modeling

\section{Introduction}

Modern progress in the methods and technologies to develop mineral deposits and geothermal resources means the necessity of deep-depth operations in hard and very hard rock [1], [2]. To increase the breaking efficiency of such rock, it is expedient to apply the action of various physical fields apart from the mechanical breaking methods. In particular, use of high-intensity heat flows is one of the most promising methods to increase the drilling velocity of brittle rock. Paper [3] demonstrates that the use of concentrated flows of heat energy for rock breaking makes it possible to increase considerably the value of specific breaking energy comparing to the rotary drilling.
Heat action is used as a main or additional factor of rock weakening in terms of thermal drilling technologies: spallation drilling [4], laser drilling [5], some combined drilling methods [6] etc. It is known that a heat factor allows intensifying the breaking processes while using traditional rotary drilling [7], [8].

Recently, certain interest has been observed in the application of low-temperature plasma action of rock [9]. Such contactless drilling method helps reduce considerably the time spent for technological operations; it is also more economically expedient comparing to the flame drilling method.

However, a technology of deep-well plasma drilling has not been widely used today, being at the stage of experimental studies. That is due to certain technical reasons, the 
necessity to develop special methods for breaking products removal from the bottomhole surface etc. At the same time, the mentioned type of action may be an efficient breaking tool in terms of hole-reaming technologies, i.e. for making underground cavities during the drilling-and-blasting operations [10].

Development and implementation of plasma-based technological processes aimed at brittle crushing of hard rock require overall studies of physical and chemical processes occurring in terms of heat action on the sock surface [11]. That will help reveal the breaking mechanisms and substantiate rational parameters of the plasma-based action. Thermal stresses in the rock should be one of the issues to be analyzed in the framework of those studies. In this case, mathematical modeling is quite an efficient research tool. Objective of the research is the development of a mathematical model and study of heat and mechanical fields within the borehole wall being under the high-intensity plasma jet action. Following tasks have been formulated and solved to achieve the objective:

- analysis of physical processes within the rock in terms of high-intensity heat action;

- development of a mathematical model of thermomechanical processes within the borehole wall in terms of plasma action;

- numerical study and analysis of thermomechanical fields within the borehole walls.

\section{Brief characteristics of the advanced plasma-based technology for well reaming}

The Institute of Geotechnical Mechanics named by N. Poljakov of National Academy of Sciences of Ukraine (IGTM of NAS of Ukraine) has developed a high-efficiency combined underground drilling-around technology for blocks. The technology involves drilling of a pioneer well of $105 \mathrm{~mm}$ in diameter with the help of mechanical rigs with further reaming by 3-6 times by means of plasma-based technique. Greater advantage of the proposed technology is in its possibility to form cavities of the specified configuration.

Nowadays, we can tell with good reason about lowtemperature plasma as about the important element of new industrial technologies for deposit development. Owing to high temperature, plasma demonstrates considerable energy deposition on the substance being treated, acting booth as a universal heat carrier and as a reagent.

Several modifications of plasma plants have been made with $150-200 \mathrm{~kW} \cdot \mathrm{s}$ power and with plasma-generating gas in the air aimed at hard rock breaking. Simple design of plasmotrons makes it possible to manufacture them at any mine in a mechanical workshop. Plasma-based well-reaming plant (PBWRP) is in the form of self-propelled semi-automatic drum-type aggregate with a mechanism of multilayered laying of a flexible feed device (cable-hose), being $75 \mathrm{~m}$ long, connected with an electric-arc plasmotron and a power supply unit. Electric-arc plasmotron is aimed for transformation of electric energy into heat one with flame temperature of $3500-4000^{\circ} \mathrm{C}$ to break hard ores. Figure 1 shows one of the PBWRP modifications.

A plant is powered by direct current supplied from a semiconductor power transformer at about $10^{3} \mathrm{~V}$ voltage; it can move within a mine working with the incline up to $10^{\circ}$. The plant operates from the mine network of compressed air. Figure 2 represents a schematic of PBWRP plant in position in the face.

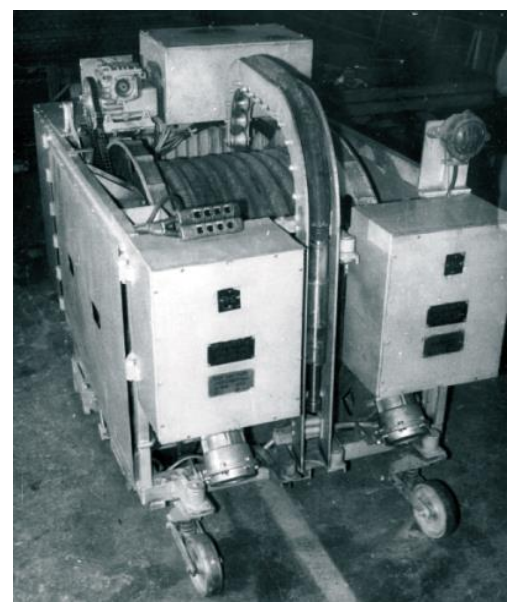

Figure 1. General view of the PBWRP plasmotron [11]

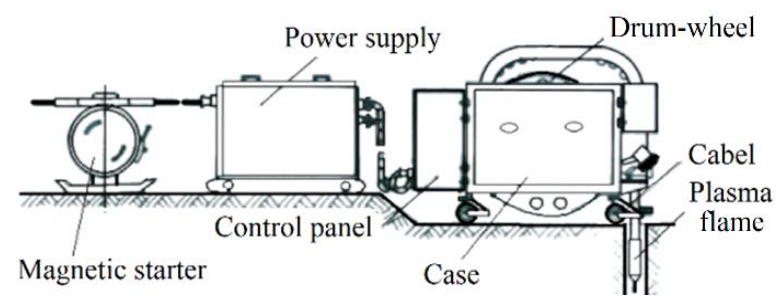

Figure 2. Schematic of PBWRP in mine

Plants and technology of plasma-based borehole reaming were tested underground in terms of Kryvbas mines while reaming a perimeter borehole to drive a ventilation rise in silicate-magnetite quartzites (M.M. Protodiakonov hardness scale is $f=15-18$ ) and magnetite-martite quartzites (hardness is $f=16-18$ ). The Table 1 shows the results of industrial tests of reaming of $105 \mathrm{~mm}$ pioneer borehole.

\begin{tabular}{|c|c|}
\hline $\begin{array}{l}\text { Diameter of reamed } \\
\text { borehole, up to, mm }\end{array}$ & $\begin{array}{c}\text { Penetration } \\
\text { rate, } \mathrm{m} / \mathrm{hr}\end{array}$ \\
\hline $200-250$ & $4.1-2.8$ \\
\hline $300-350$ & $2.5-1.1$ \\
\hline $450-500$ & $0.45-0.4$ \\
\hline
\end{tabular}

The results obtained after industrial tests [10], [11] indicate high efficiency of a plasma-based rock-breaking technique. It has been proved that a thermal method (plasmabased) is expedient to be used while breaking hard ores and different metasomatosis. Moreover, use of plasma plants for borehole reaming allows reducing considerably the number of boreholes, eliminating sublevels, accelerating preparation of blocks for their development etc.

Today, there are sources of overheated steam (up to $4000^{\circ} \mathrm{C}$ ) developed at the IGTM of NAS of Ukraine; the sources make it possible to apply steam as a plasmagenerating gas and obtain environmentally friendly plasmotrons and technologies.

The IGTM of NAS of Ukraine carried out the laboratory analysis of thermal-destruction products obtained during the industrial experiments. Thermogravimetric studies with the help of a derivatograph have shown that rock is broken at the temperature of $320-350^{\circ} \mathrm{C}$ though, during the borehole reaming, the temperature may reach up to $1200-600^{\circ} \mathrm{C}$. Calculation of the activation power has shown that in 20 minutes of plasma jet action, activation energy increases twofold within 
the zone of heat destruction in terms of maximum plant efficiency. Petrographic studies have demonstrated that the heat effect results in physicochemical transformations, gaseous phase outgoing, porosity increase, rock softening etc. A fracture formation process experiences its intensification within the pre-breaking zone due to intense heat action. In general, one can state that plasma-based action on the rock results in the multifactor complex effect on a physical state being not revealed completely up to now; that stipulates the necessity of carrying out the corresponding studies.

\section{Studying a thermoelastic state of the borehole walls while plasma-based rock breaking}

\subsection{Physical statement of the problem}

Rock breaking under heat action is stipulated by the irreversible structural changes and effect of thermal stresses. Thermodynamic aspects of the rock breaking process are considered in [12]. Basics of the theory of rock breaking under heat action were developed in [13]. The approach is based on classic thermoelasticity. Brittle rock breaking is substantiated in terms of the first theory of strength. At the expense of heating, thermal compression stresses are induced in the rock; those stresses favour intensification of a fracturing process. The model has been developed practically in experimental [14]-[16] and theoretical [17] works dealing with the substantiation of thermal methods of drilling.

That model was developed in paper [18] to study fracturing processes in terms of sign-variable heat action. Study [19] represents a mathematical model of spalling of the bottomhole plane under the effect of compressing thermal stresses.

Note that a plasma-based well reaming has certain features. Taking into account high temperature of plasma jet, it is necessary to consider radiation heat flow while modeling heat transfer. Moreover, one should remember that mechanical properties of the rock depend on temperature as well; and the model itself requires using not plane but cylindrical coordinate system.

Represent the rock around borehole with radius $R$ as a cylindrical elastic semi-space with the coordinate origin in the borehole centre (Fig. 3a). A scheme of rock spalling under the heat action is represented in Figure 3.

At some initial moment of time, the borehole wall starts being warmed-up under the plasma jet action (Fig. 3b). Due to the induced thermal stresses, there is a start of microfractures growth and surface buckling (Fig. 3c). When a spall is formed, it separates from the rock mass (Fig. 3d).

\subsection{Mathematical statement of the problem}

In general, it should be considered that the heating process is accompanied by the changing parameters of jet-wall heat exchange due to the surface distancing from the source. However, consider that the heat exchange parameters are constant for the initial period of time. The first approximation will involve examination of the processes of heat transfer only in radial direction. We will take into consideration the radiation heat exchange on the wall surface as the plasma temperature reaches rather high values.

Thus, a mathematical model of heat transfer in the rock will be as follows:

$c \rho \frac{\partial T}{\partial \tau}=\frac{1}{r} \cdot \frac{\partial}{\partial r}\left(r \lambda(T) \frac{\partial T}{\partial r}\right), \tau>0, R \leq \tau<\infty$. (a)

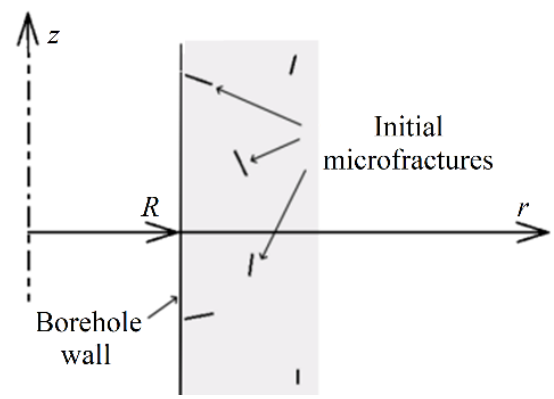

(b)

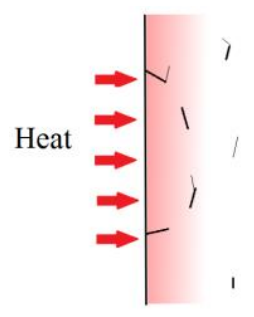

(c)

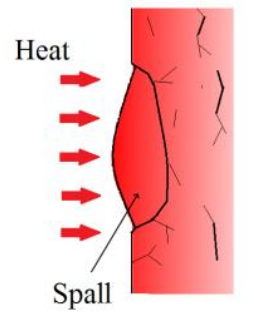

(d)

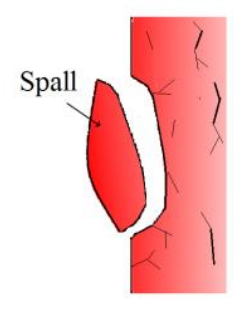

Figure 3. A physical model of thermal rock disintegration: cold rock (a); wall heating and growth of microcracks (b); buckling of the surface and formation of a new spall (c); spall deataching (d)

$\left.T\right|_{\tau=0}=T_{0}(z)$

$\left.\left(\lambda \frac{\partial T}{\partial r}\right)\right|_{r=R}=-\alpha\left(T_{\text {plasma }}-\left.T\right|_{r=R}\right)+$

$+C\left(\left(\frac{T_{\text {plasma }}}{100}\right)^{4}-\left(\frac{\left.T\right|_{r=R}}{100}\right)^{4}\right)$

$\left.\frac{\partial T}{\partial r}\right|_{r \rightarrow \infty}=0$

where:

$T$ - temperature;

$\tau$ - time;

$r$ - radial coordinate;

$c$ - heat capacity of the rock;

$\rho$ - rock density;

$\lambda$ - heat conductivity of the rock;

$T_{0}$ - initial temperature of the rock depending on the depth;

$\alpha$ - heat transfer coefficient on the surface;

$C$ - reduced coefficient of radiation heat exchange.

The initial rock temperature is a function of the borehole depth and depends on specific geological conditions [20].

The reduced coefficient of radiation heat exchange is determined as follows:

$$
C=\frac{C_{0}}{\frac{1}{\varepsilon_{\text {plasma }}}+\frac{1}{\varepsilon_{\text {rock }}}-1},
$$

where:

$$
\begin{aligned}
& C_{0}=5.67 \cdot 10^{-8} \mathrm{~W} /\left(\mathrm{m}^{2} \cdot \mathrm{K}^{4}\right) \\
& \varepsilon_{\text {plasma }} \text { - radiation emissivity of a plasma jet; } \\
& \varepsilon_{\text {rock }} \text { - radiation emissivity of the rock. }
\end{aligned}
$$


Determining the plasma emissivity factor is a separate nontrivial problem. The current research takes the data from paper [21] to calculate the emissivity factor for hightemperature air in terms of atmospheric pressure. Such an approach is reasonable as it is the air plasma that is used in mine plasmotrons.

Results of paper [22] were used to determine the heat exchange coefficient.

Despite the fact that the available analytical solutions of a problem on heat transfer in the borehole-surrounding rock [23], problem (1)-(4) was solved by numerical method due to nonlinearity of equation (1) and condition (3).

Assuming that a rule of superposition is true for mechanical fields, we will consider only thermal stresses in the rock. To model the fields of thermal stresses around the borehole, a solution of the corresponding thermoelasticity problem [24] was applied. According to that solution, thermal stresses and deformations are determined by following expressions:

$$
\begin{aligned}
& \sigma_{r}=\frac{\beta E}{(1-\mu) r^{2}}\left[\frac{r^{2}-R^{2}}{R_{T}^{2}-R^{2}} \int_{R}^{R_{T}} r \Theta(r, \tau) d r-\int_{R}^{r} r \Theta(r, \tau) d r\right] \\
& \sigma_{\phi}=\frac{\beta E}{(1-\mu) r^{2}}\left[\frac{r^{2}+R^{2}}{R_{T}^{2}-R^{2}} \int_{R}^{R_{T}} r \Theta(r, \tau) d r+\right. \\
& \left.+\int_{R}^{r} r \Theta(r, \tau) d r-r^{2} \Theta(r, \tau)\right] \\
& \sigma_{z}=\sigma_{\phi}+\sigma_{r} ; \\
& \varepsilon_{\phi}=\frac{u_{r}}{r} ; \\
& \varepsilon_{\phi}=\frac{1-\mu^{2}}{E}\left(\sigma_{\phi}-\frac{\mu}{1-\mu} \sigma_{r}\right)+\beta(1+\mu) \Theta(r, \tau)
\end{aligned}
$$

where:

$\beta$ - coefficient of heat expansion of the rock;

$E$ - Young's modulus;

$\mu$ - Poison's ratio;

$\sigma$-stresses;

$\varepsilon$ - deformations;

$u$ - displacements, indices;

$r, \varphi$ and $z$-correspond to the coordinate directions of a cylindrical coordinate system;

$\Theta(r, \tau)=T(r, \tau)-T_{0}$

$R_{T}$ - radius of heat action.

Value $R_{T}$ determines dimensions of the excited heat field [25]. Thus, if $r=R_{T}$, following condition is taken:

$\sigma_{r}=\sigma_{z}=\sigma_{\phi}=0$.

Value $R_{T}$ is identified from the solution of problem (1)-(4).

\section{Calculation results and discussion}

Consider the example of the calculation of temperature fields and stresses within the granite mass surrounding the borehole in terms of low-temperature plasma jet acting on the plant surface. There are following specified initial data for the calculation: $T_{0}=298 \mathrm{~K} ; T_{\text {plasma }}=3000 \mathrm{~K} ; \alpha=100 \mathrm{~W} /\left(\mathrm{m}^{2} \mathrm{~K}\right)$; $C=0.0024 \mathrm{~W} /\left(\mathrm{m}^{2} \mathrm{~K}^{4}\right) ; \quad c=922 \mathrm{~J} /(\mathrm{kg} \cdot \mathrm{K}) ; \rho=2720 \mathrm{~kg} / \mathrm{m}^{3}$; and $R=0.05 \mathrm{~m}$.
Changes in thermophysical and mechanical granite properties depending on the temperature were approximated according to the experimental data [26]:

$$
\lambda=\frac{474}{350+T}+1.18
$$

$E=(11.09 T-0.012) \cdot 10^{9}$;

$\beta=\left(3.569 \cdot 10^{-3} T-0.792\right) \cdot 10^{-5}$.

Figure 4 represents the results of calculation of temperature field within the borehole-surrounding rock.

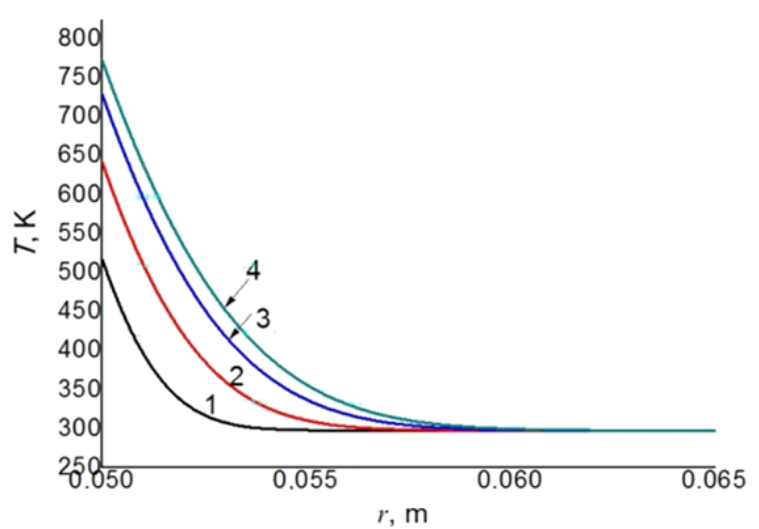

Figure 4. Changes in temperature $T$ along radius $r$ for different moments of time $\tau: 1-2 s ; 2-5 s ; 3-8 s ; 4-9.8 s$

As the data in Figure 4 show, a high temperature region localizes within a thin layer $(\approx 5-10 \mathrm{~mm})$ adjoining the borehole wall. In about $9.8 \mathrm{~s}$ after the start of heating, surface temperature reaches $773 \mathrm{~K}$ that corresponds to the value at which most thermally drilled rocks start spalling.

Figure 5 shows distribution of temperature stresses in azimuth direction. Figure 6 shows that in axial direction/ And Figure 7 demonstrates that in radial directions.

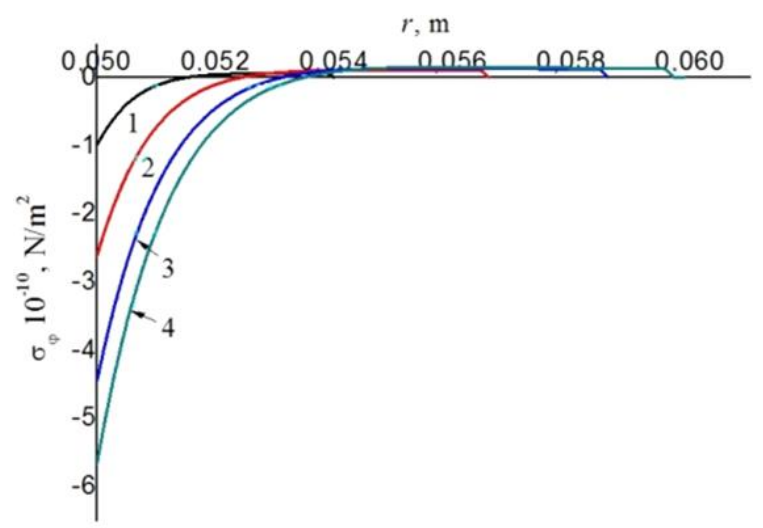

Figure 5. Distribution of azimuth thermal stresses $\sigma_{\varphi}$ along radius $r$ for different moments of time $\tau: 1-2 s ; 2-5 s$; $3-8 s ; 4-9.8 s$

As it is seen from the data representing different moments of time $\tau(1-2 \mathrm{~s} ; 2-5 \mathrm{~s} ; 3-8 \mathrm{~s}$; and $4-9.8 \mathrm{~s})$, temperature increase in the rock is accompanied by the developing thermal compressing stresses. According to the data [27], absolute values of boundary thermal compressing stresses for granite are $1.66 \cdot 10^{8}-2.59 \cdot 10^{8} \mathrm{~N} / \mathrm{m}^{2}$. 


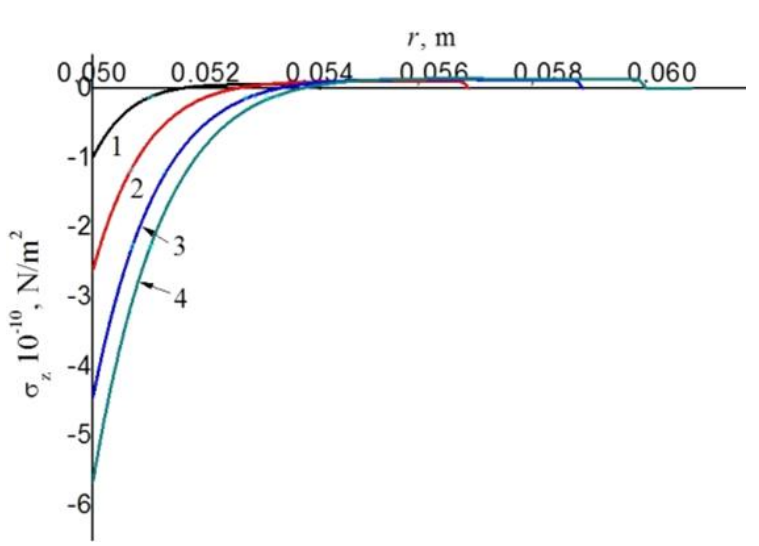

Figure 6. Distribution of axial thermal stresses $\sigma_{2}$ along radius $r$ for different moments of time $\tau: 1-2 \mathrm{~s} ; 2-5 \mathrm{~s} ; 3-8 \mathrm{~s} ; 4-9.8 \mathrm{~s}$

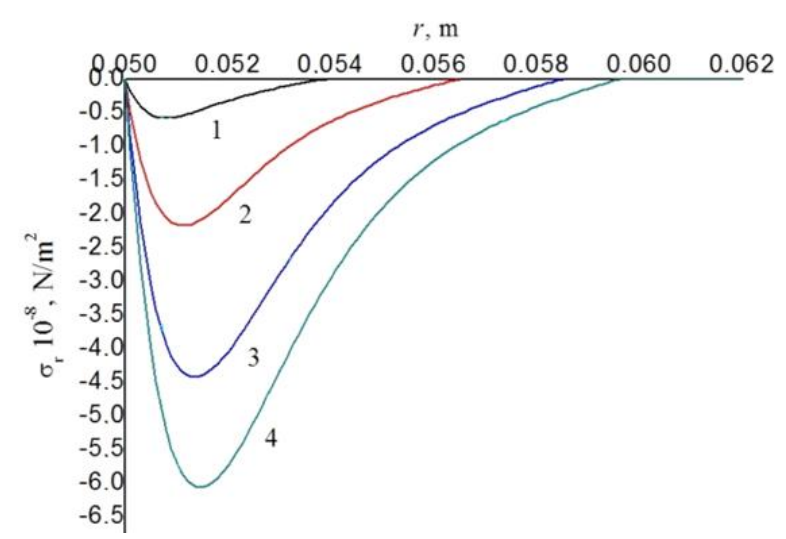

Figure 7. Distribution of radial thermal stresses $\sigma_{r}$ along radius $r$ for different moments of time $\tau: 1-2 s ; 2-5 s ; 3-8 s ; 4-9.8 s$

Axial and azimuth stressses have the highest values; they are close in values and distribution being two-order more than the radial ones. In turn, values of radial stresses are comparable with the boundary ones. Thus, in case of plasma action, values of thermal compressing stresses may exceed the indicated values.

According to formula (8), thermal stresses result in the starting process of surface distortion (buckling) and new spall formation. Values of surface buckling $h$ can be determined as the displacement in radial direction. Figure 8 shows value $h=u_{r}$ calculated according to ratio (8).

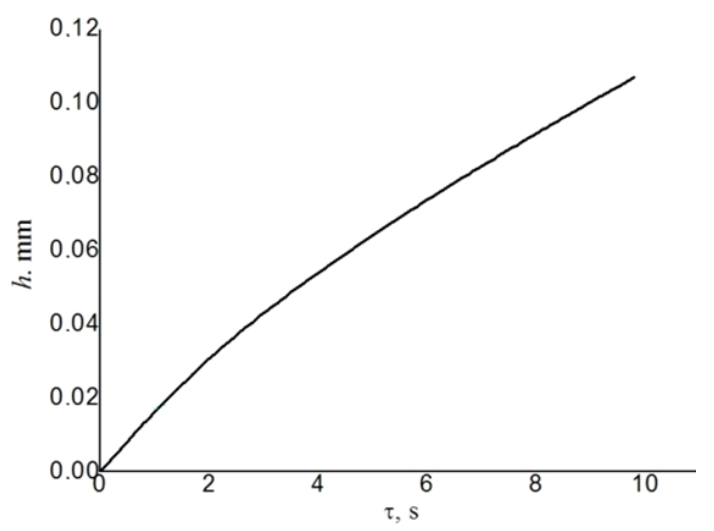

Figure 8. Displacement of surface $h$ in radial direction depending on time $\tau$

The data represented in Figure 8 demonstrate that the wall distortion reached $0.11 \mathrm{~mm}$ in $9.8 \mathrm{~s}$.
The value of thermoelastic distortion of the surface profile, thickness of the heated layer, position of the point of radial stresses maximum - those parameters characterize indirectly the sizes of rock spalls and may be used for theoretical evaluation of the rock breaking parameters.

\section{Conclusions}

High-temperature plasma jet helps heat up a thin layer of the rock adjoining the borehole wall. Heating time up to the breaking temperature is about $9.8 \mathrm{~s}$ at the plasma jet temperature of $3500-4000^{\circ} \mathrm{C}$; in this context, heated layer thickness is less then $10 \mathrm{~mm}$.

Thermal compressing stresses occur within the heated rock layer. While analyzing the parameters of plasma effect on granite, radial thermal stresses reach boundary values of compression stress while axial and azimuth values exceed the radial ones by two orders. During the action time of $9.8 \mathrm{~s}$, the borehole wall profile experiences more than $0.1 \mathrm{~mm}$ distortions, being comparable with the spall thickness. Thus, a process of rock fracturing is provided both on the borehole wall (at the expense of profile distortion) and within the volume of heated-up layer (at the expense of radial thermal stresses).

The represented model may be proposed to study a process of borehole wall breaking in terms of intense heat action.

\section{Acknowledgements}

The part of paper materials come from the results of $R \& D$ activities concerning the development of plasma-based borehole-reaming technology carried out in the Institute of Geotechnical Mechanics named by N. Poljakov of National Academy of Sciences of Ukraine (IGTM of NAS of Ukraine). The authors express their gratitude to all the participating colleagues.

\section{References}

[1] Pivnyak, G., Bondarenko, V., \& Kovalevska, I. (2015). New developments in mining engineering 2015: Theoretical and practical solutions of mineral resources mining. London, United Kingdom: CRC Press, Taylor \& Francis Group, 607 p. https://doi.org/10.1201/b19901

[2] Dychkovskyi, R., Vladyko, O., Maltsev, D., \& Cáceres Cabana, E. (2018). Some aspects of the compatibility of mineral mining technologies. Rudarsko Geolosko Naftni Zbornik, 42(4), 73-82. https://doi.org/10.17794/rgn.2018.4.7

[3] Ndeda, R., Sebusang, E., Marumo, R., \& Ogur, E. (2015) Review of thermal surface drilling technologies. Proceedings of Sustainable Research and Innovation Conference, 61-69.

[4] Wilkinson, M.A., \& Tester, J.W. (1993). Experimental measurement of surface temperatures during flame-jet induced thermal spallation. Rock Mechanics and Rock Engineering, 26(1), 29-62. https://doi.org/10.1007/bf01019868

[5] Yang, Y., Chen, Z., \& Zhang, Y. (2016). Melt flow and heat transfer in laser drilling. International Journal of Thermal Sciences, (107), 141-152. https://doi.org/10.1016/j.ijthermalsci.2016.04.006

[6] Rossi, E., Jamali, S., Wittig, V., Saar, M.O., \& von Rohr, P.R. (2020). A combined thermo-mechanical drilling technology for deep geothermal and hard rock reservoirs. Geothermics, (85), 101771. https://doi.org/10.1016/i.geothermics.2019.101771

[7] Cao, X, Kozhevnykov, A., Dreus, A., \& Liu, B. (2019). Diamond core drilling process using intermittent flushing mode. Arabian Journal of Geosciences, 12(4), 137. https://doi.org/10.1007/s12517-019-4287-2

[8] Dreus, A., \& Kozhevnykov, A. (2019) Innovative approach to drilling of geothermal deep wells using the heat factor. IEEE $6^{\text {th }}$ International Conference on Energy Smart Systems, 192-195, https://doi.org/10.1109/ESS.2019.8764208

[9] Kocis, I., Kristofic, T., Gebura, M., Horvath, G., Gajdos, M., \& Stofanik, V. (2017). Novel deep drilling technology based on electric plasma developed in Slovakia. 2017 XXXII ${ }^{\text {nd }}$ General Assembly and Scientific 
Symposium of the International Union of Radio Science (URSI GASS), 1-4. https://doi.org/10.23919/ursigass.2017.8105224

[10] Bulat, A.F., Nikiforova, V.A., \& Osenniy, V.Ya. (2006). Improving the efficiency of drilling and blasting operations in the hard ores. Visnyk KSPI, 2(37), 93-94.

[11] Osenniy, V.Ya. (2012). On a model for creating a boiler cavity by a plasma heat generator. Geotechnical Mechanics, (98), 254-262.

[12] Mashchenko, V.A., Khomenko, O.Ye., \& Kvasnikov, V.P. (2020). Thermodynamic aspect of rock destruction. Naukovyi Visnyk Natsionalnoho Hirnychoho Universytetu, (1), 25-30 https://doi.org/10.33271/nvngu/2020-1/025

[13] Dmitriev, A.P., Goncharov, S.A., \& Germanovich, L.N. (1990). Thermal destruction of rocks. Moscow, Russian Federation: Nedra, $255 \mathrm{p}$.

[14] Lyu, Z., Song, X., Shi, Y., Li, G., Hu, X., Zheng, R., \& Wang, G. (2017). Experimental study on specific energy of thermal spallation drilling technology. $51^{s t}$ U.S. Rock Mechanics/Geomechanics Symposium, USA ARMA-2017-0279.

[15] Voloshyn, O., Potapchuk, I., Zhevzhyk, O. \& Zhovtonoha, M. (2018). Results of the experimental research of the heat-transfer jet pressure to the rock surface during thermal reaming of the borehole. E3S Web of Conferences, (60), 00024. https://doi.org/10.1051/e3sconf/20186000024

[16] Kant, M.A., Rossi, E., Madonna, C.D., Höser, D., \& Rudolf von Rohr, P. (2017). A theory on thermal spalling of rocks with a focus on thermal spallation drilling. Journal of Geophysical Research: Solid Earth, 122(3), 1805-1815. https://doi.org/10.1002/2016JB013800

[17] Mardoukhi, A., Saksala, T., Hokka, M., \& Kuokkala, V.-T. (2017). A numerical and experimental study on the tensile behavior of plasma shocked granite under dynamic loading. Rakenteiden Mekaniikka, 50(2), 41-62. https://doi.org/10.23998/rm.65301

[18] Dreus, A.Yu., Sudakov, A.K., Kozhevnikov, A.A., \& Vakhalin, Yu.N. (2016). Study on thermal strength reduction of rock formation in the diamond core drilling process using pulse flushing mode. Naukovyi Visnyk Natsionalnoho Hirnychoho Universytetu, (3), 5-10.

[19] Walsh, S.D., Lomov, I., \& Roberts, J.J. (2011). Geomechanical modeling for thermal spallation drilling. Geothermal Resources Council Annual Meeting 2011, 277-282.

[20] Bulat, A., Blyuss, B., Dreus, A., Liu, B., \& Dziuba, S. (2019). Modelling of deep wells thermal modes. Mining of Mineral Deposits, 13(1), 58-65. https://doi.org/10.33271/mining 13.01.058

[21] Biberman, L.M., \& Mnathakanyan, A.Kh. (1966). The optical properties of air in the temperature range 4000-10000 K. Teplofizika Vysokikh Temperatur, 4(2), 148-159.

[22] Sary, G., Dufour, G., Rogier, F., \& Kourtzanidis, K. (2014). Modeling and parametric study of a plasma synthetic jet for flow control. AIAA Journal, 52(8), 1591-1603. https://doi.org/10.2514/1.j052521

[23] Philippe, M., Bernier, M., \& Marchio, D. (2009). Validity ranges of three analytical solutions to heat transfer in the vicinity of single boreholes. Geothermics, 38(4), 407-413. https://doi.org/10.1016/..geothermics.2009.07.002

[24] Kovalenko, A.D. (1975). Thermoelasticity. Kyiv, Ukraine: Naukova dumka, $216 \mathrm{p}$.

[25] Sudakov, A.K., Dreus, A.Yu., Khomenko, O.Ye., \& Sudakova, D.A. (2017). Analytical study of heat transfer in absorptive horizons of borehole at forming cryogenic protecting of the plugging material Naukovyi Visnyk Natsionalnoho Hirnychoho Universytetu, (3), 38-42.

[26] Vosteen, H.D., \& Schellschmidt, R. (2003). Influence of temperature on thermal conductivity, thermal capacity and thermal diffusivity for different types of rock. Physics and Chemistry of the Earth, (28), 499-509. https://doi.org/10.1016/S1474-7065(03)00069-X

[27] Moskalev, A.N., Pigida, Ye.Yu., Kerekelitsa, L.G., \& Vakhalin, Yu.N. (1987). The destruction of rocks during thermocyclic exposure. Kyiv, Ukraine: Naukova dumka, $248 \mathrm{p}$

\section{Математичне моделювання термічних напружень у стінці свердловини при плазмовому впливі}

\section{А. Булат, В. Осінній, А. Дреус, Н. Осіння}

Мета. Розробка математичної моделі для дослідження і опису термічних процесів в стінці свердловини при плазмовому руйнуванні гірської породи.

Методика. Застосовано теоретичний аналіз в рамках теорії крихкого руйнування термопружності, методи математичного моделювання та обчислювальний експеримент.

Результати. Представлена коротка інформація за результатами розробки перспективної плазмової технології розширення свердловин при видобутку твердих корисних копалин. Представлені результаи промислових випробувань плазмової установки (УПС) потужністю 150-200 кВт з плазмоутворюючим газом на повітрі для руйнування міцних порід. Установка і технологія плазмового розширення свердловин були випробувані в підземних умовах рудників Кривбасу при розширенні компенсаційної свердловини для проходки вентиляційної повстає вироблення в силікатно-магнетитових кварцитів. Запропоновано розроблену математичну модель для дослідження теплових і механічних полів в гірській породі при плазмовому впливі на стінку свердловини. Виконано чисельні дослідження динаміки температури і термічних напружень в навколишньому свердловину шарі гірської породи. Показано, що при використанні низькотемпературної плазми $(T=3500-4000 \mathrm{~K})$ в тонкому шарі гірської породи індукуються термічні напруги стиснення, які можуть перевищувати гранично допустимі. Визначено, що вплив плазмового струменя на стінку свердловини дозволяє створити умови для інтенсивного розтріскування і руйнування гірської породи.

Наукова новизна. Отримано розв'язок нової задачі о термопружном стані стінки свердловини при впливі плазмового струменю. Запропонована математична модель сформульована в циліндричній системі координат і враховує конвективний і радіаційний теплообмін між плазмовим струменем і стінкою свердловини.

Практична значимість. Отримані результати дозволяють оцінювати термонапруженого стан гірської породи в залежності від параметрів плазмового струменя. Запропонована методика розрахунку дозволить проводити дослідження для оцінки параметрів руйнування (необхідний час нагрівання, товщину прогрітого шару і приблизні розміри Шелушков) і розробити методи управління процесом руйнування.

Ключові слова: плазмова технологія, термічні напруги, теплопередача, розиирення свердловини, математичне моделювання

\section{Математическое моделирование термических напряжений в стенке скважины при плазменном воздействии}

\section{А. Булат, В. Осенний, А. Дреус, Н. Осенняя}

Цель. Разработка математической модели для исследования и описания термических процессов в стенке скважины при плазменном разрушении горной породы.

Методика. Применен теоретический анализ в рамках теории хрупкого разрушения термоупругости, методы математического моделирования и вычислительный эксперимент.

Результаты. Представлена короткая информация по результатам разработки перспективной плазменной технологии расширения скважин при добыче твердых полезных ископаемых. Представлены результаты промышленных испытаний плазменной установки мощностью 150-200 кВт с плазмообразующим газом на воздухе для разрушения крепких пород. Установка и технология плазменного расширения скважин были опробованы в подземных условиях рудников Кривбасса при расширении компенсационной скважины для проходки вентиляционной восстающей выработки в силикатно-магнетитовых кварцитах. Предложена математическая модель для исследования тепловых и механических полей в горной породе при плазменном воздействии на стенку скважи- 
ны. Выполнены численные исследования динамики температуры и термических напряжений в окружающем скважину слое горной породы. Показано, что при использовании низкотемпературной плазмы ( $T=3500-4000$ К) в тонком слое горной породы индуцируются термические напряжения сжатия, которые могут превышать предельно допустимые. Определено, что плазменное воздействие на стенку скважины позволяет создать условия для интенсивного растрескивания и разрушения горной породы.

Научная новизна. Получено решение новой задачи о термоупругом состоянии стенки скважины при плазменном воздействии. Предложенная математическая модель сформулирована в цилиндрической системе координат и учитывает конвективный и радиационный теплообмен между плазменной струей и стенкой скважины.

Практическая значимость. Полученные результаты позволяют оценивать термонапряженное состояние горной породы в зависимости от параметров плазменной струи. Предложенная методика расчета позволит проводить исследования для оценки параметров разрушения (необходимое время нагрева, толщину прогретого слоя и приблизительные размеры шелушки) и разработать методы управления процессом разрушения.

Ключевые слова: плазменная технология, термические напряжения, теплоперенос, расширение скважины, математическое моделирование 